Government Matters 



\title{
Government Matters
}

\section{WELFARE REFORM IN WISCONSIN}

\author{
Lawrence M. Mead
}

PRINCETON UNIVERS ITY PRESS

PRINCETON AND OXFORD 
Copyright $\odot 2004$ by Princeton University Press

Published by Princeton University Press, 41 William Street,

Princeton, New Jersey 08540

In the United Kingdom: Princeton University Press,

3 Market Place, Woodstock, Oxfordshire OX20 1SY

All Rights Reserved.

Library of Congress Cataloging-in-Publication Data

Mead, Lawrence M.

Government matters : welfare reform in Wisconsin / Lawrence M. Mead.

p. $\mathrm{cm}$.

Includes bibliographical references and index.

ISBN 0-691-11646-6

1. Public welfare-Wisconsin. 2. Wisconsin-Politics and government-1951- I. Title.

HV98.W6M4 2004

$361.6^{\prime} 8^{\prime} 09775-\mathrm{dc} 21 \quad 2003051767$

British Library Cataloging-in-Publication Data is available.

This book has been composed in Sabon

Printed on acid-free paper. $\infty$

www.pupress.princeton.edu

Printed in the United States of America

$\begin{array}{llllllllll}10 & 9 & 8 & 7 & 6 & 5 & 4 & 3 & 2 & 1\end{array}$ 
This book is dedicated to the welfare administrators of Wisconsin and the nation. 
